Informasi - ISSN (p) 0126-0650; ISSN (e) 2502-3837

Vol. 5o, No. 2 (2020), pp. 137-152 doi: http://doi.org/10.21831/informasi.v50i2.29786

\title{
Stakeholder collaboration to build peace through public interest relations (PIR) (Study on the commemoration of Suran Agung conflict in Madiun)
}

\author{
Rediaz Rakhman Johan \\ Program Studi Magister Ilmu Komunikasi \\ Universitas Sebelas Maret Surakarta, Indonesia \\ rediazrj@student.uns.ac.id \\ Sri Hastjarjo \\ Program Studi Magister Ilmu Komunikasi \\ Universitas Sebelas Maret Surakarta, Indonesia \\ sri.hastjarjo@staff.uns.ac.id \\ Ignatius Agung Satyawan \\ Program Studi Magister Ilmu Komunikasi \\ Universitas Sebelas Maret Surakarta, Indonesia \\ agungsatyawan@staff.uns.ac.id
}

Article History: Received 2020-01-22, Revised 2020-11-05, Accepted 2020-11-17

\begin{abstract}
Madiun Regency is one area that has a lot of active silat colleges, there are 14 (fourteen) silat colleges, mostly based in Madiun. In the dynamics of Madiun pencak silat development, there is Suran Agung tradition as a form of local wisdom in every pencak silat college at the suro month. The activity involved mass mobilization, the escalation of conflict between members of the martial arts college and communities also increased. The history of the conflict began when there was fanaticism of teachings from the Ki Ngabei Soerodiwiryo students. Conflicts that occurred in the Suran Agung involved between groups of fighters and community which often caused material losses such as throwing stones, destruction of public facilities also lead to violence resulting in casualties. Qualitative research here to analyze the efforts of the District Government of Madiun in preventing conflict that is an issue for the public, the Public Interest Relations (PIR) approach to the practice of Suran Agung in Madiun focuses on stakeholder collaboration in peace efforts. The result of PIR practice is the emergence of a new identity for Indonesian Pesilat Village as a milestone for peace in social change to realize the vision and mission of regional head.
\end{abstract}

Keywords: Public Interest Relation, Collaboration, Social Conflict, Stakeholders, Peace. 


\section{INTRODUCTION}

As a multicultural country, Indonesian society consists of various cultural communities that have advantages in values, history, customs, traditions, forms of social organization (Parekh, 2008). Multiculturalism is the wisdom to see cultural diversity as a fundamental reality in social life (Lutfi \& Fathani, 2013). One form of multiculturalism of Indonesian society is a phenomenon in Madiun Regency, there are a number of active Pencak Silat institutions based in Madiun and an annual cultural tradition called Suran Agung. Based on data from Bakesbangpoldagri Madiun Regency, a total of 14 (fourteen) martial arts institutions are mostly based in Madiun Regency, there are: Setia Hati Tuhu Tekad, the Setia Hati Tunas Muda Winongo Brotherhood, the Setia Hati Terate Brotherhood, IKS Pro Patria, Ki Ageng Pandan Alas, IKS PI Kera Sakti, Brotherhood of Sehati, Betako Merpati Putih, Tapak Suci, Cempaka Putih, Pagar Nusa, Persinas ASAD, Persaudaraan Rasa Tunggal, OCC Pangastuti.

The tradition of Suran Agung is a form of local wisdom that exists in the Madiun region just before the month of Suro and is routinely scheduled once a year and there is a large and centralized mobilization of masses in the Madiun area. This condition causes have positive and negative sides, mobilization of masses is an attractive potential for Madiun region, but on the other side there is a potential conflict between warrior and with the community. Form of conflict that occurs is horizontal conflict; this conflict involves groups of citizens and warriors.

Conflict that occurred in Suran Agung couldn't be separated from the history of Setia Hati Terate and Setia Hati Tunas Muda Winongo, both of which came from one brotherhood, namely Setia Hati which was founded by Ki Ngabei Soerodiwiryo. The belief in followers of two institution raises a claim from each party as the bearer of pure teachings from Ki Ngabei Soerodiwiryo. The existence of these claims raises fanaticism for some groups. Another factor is the lack of understanding for some members of the teachings of Setia Hati which can lead to potential conflicts (Soebijantoro et al., 2012). Potential conflicts often occur when group members prioritize personal and group interests so that there is competition that can lead to conflict (Oetzel \& Ting-Toomey, 2006).

Stakeholders need to solve problems as a form of reconciliation conflicts that occur. Ahead of the Suran Agung celebration, Government applies the practice of Public Interest Relations (PIR) as an effort to reconcile conflicts. By prioritizing the interests of the public, public relations not only plays an important role in peace building, but can also be used in conflict negotiations (Ivana \& Krishnamurthy, 2019). Combining and integrating various interests is the focus of Public Interest Relations (PIR), Public Relations can be considered a failure if it doesn't consider the interests and responsibilities to the public (Brunner, $2017 \mathrm{~b}$ ). Expected outcome of PIR practice is to gain trust, build community, and foster goodwill across stakeholder groups. Trust is widely accepted as an essential part of public relations and can only be built with time (Ki et al., 2015).

Conflict reconciliation process from year to year until 2019 resulted in two agreements, first the declaration of peace pledge by fourteen pencak silat institutions and formation of the Indonesian Pesilat Village in Madiun Regency. The formation of Pesilat Village and declaration the pledge of peace was the first steps in a better change in history, so that the celebration of Suro which is carried out by the pencak silat institutions can run safely and peacefully for the whole community, because the potential for conflict can be eliminated. Central to PIR practice is creating room for dialogue, listening to multiple points of view, offering honest analysis of recommendations advocating and acting in the public interest, while also advancing organizational goals. (Brunner \& Smallwood, 2019). By taking the PIR approach in handling conflict from previous studies, this study aims to analyze the efforts of the Madiun Regency Government in preventing 
conflicts between groups, especially in the commemoration of Suran Agung in Madiun. This research is expected to be useful as a contribution to Communication Science, especially the formulation of a theoretical framework in building stakeholder relationships to prevent social conflicts in society. In subsequent research, it can also be used as a consideration in reconciling conflicts between groups.

\section{LITERATURE REVIEW}

\section{Suran Agung}

Suran Agung tradition is a Javanese cultural tradition when welcoming month of Sura or Muharam. During Ki Ngabehi Soerodiwirjo's life, in commemorating month of Suro he only made "suro porridge" to make ends meet. Apart from enjoying simple dishes, there are also organizing what is called "sambung" - performances to express the feeling of joy when entering Islamic New Year. Through a game called "sambung-menyambung" to become one is the meaning contained in deliberation, starting with one opinion then agreeing to reach a consensus? At first Suran Agung tradition was only attended by members who lived in Madiun City, until 1931 members who lived outside Madiun City began to celebrate it as well as a commemoration of the establishment of Setia Hati Brotherhood and an opportunity to meet with Ki Ngabehi Soerodiwirjo before he died. Tradition of Suran Agung became local wisdom in the Madiun area because it involves a very large number of people who are participated by various Pencak Silat organizations as well as the community. Of course, it is an obligation among stakeholders in preventing negative potentials in the Madiun region and can explore positive potentials that can develop for the good of community in moving the wheels of economy.

\section{History of Martial Arts Conflict in Madiun}

To reduce conflict, at least look at the root of the problem and this cannot be separated from history of Setia Hati brotherhood. Ki Ngabehi Soerodiwirjo is a central figure of Setia Hati brotherhood and was born in 1869, commonly called Eyang Suro (Soewarno, 1994). The brotherhood that he founded was very religious because he was a religious figure. 1903 was beginning of Setia Hati brotherhood which he founded was located at Tambak Gringsing, Surabaya. At that time the brotherhood was named Djojo Gendilo Cipto Mulyo, but some called it "Sadulur Tunggal Kecer" or STK (Soebijantoro et al., 2012). In 1917 Djojo Gendilo Cipto Mulyo held a show in the center of Madiun City and attracted public attention and became interested in joining Djojo Gendilo Cipto Mulyo. During the colonial period in Indonesia, the brotherhood was often suspected of being a resistance movement against the Dutch. In that year Djojo Gendilo Cipto Mulyo was changed to "Setia Hati" or SH (Joyohusodo et al., 1963).

In 1924, Eyang Suro settled in Winongo Madiun Village and still activated $\mathrm{SH}$, but the membership was very limited, because those who could join were only from the aristocracy at that time. Seeing slow potential of development in Setia Hati, one of students, Ki Hadjar Hardjo Oetomo intends to use Setia Hati as a means of struggle to fight colonialism by spreading teachings to all groups including the lower class. However, that intention was conflicted because the teachings SH couldn't be done to everyone and everywhere (Maksum, 2009). In $1922 \mathrm{Ki}$ Hadjar Hardjo Oetomo finally formed the SH Pencak Sport Club which was located in Pilangbangau Madiun Village and this was the forerunner of SH Terate (Harsono, 2000). For the formation of SH Pencak Sport Club, Eyang Suro didn't necessarily prohibit or bless it because it was a personal responsibility. Until 10 November 1944 at the age 75, Eyang Suro died due to illness. Before his death, Eyang Suro advised Setia Hati brotherhood to remain harmonious and united, he also donated his residence to Setia Hati (Soebijantoro et al., 2012). 
After the death of Eyang Suro, in 19451950 leadership was replaced by Koesnendar who also served as Regent and formed $\mathrm{SH}$ Panti. The development of SH Panti didn't go well because there wasn't regeneration because recruitment of members was very limited. This situation continued until second leadership by Hadi Subroto in 19501978. During Subroto's time, SH Panti was split on 15 October 1965. R. Djimat Hendro Soewarno from youth community took initiative to form SH Winongo Tunas Muda which was also based in Winongo Village at residence of $\mathrm{R}$. Soewarno (Soewarno, 1994). Even though they are both centered in Winongo area, there is no organizational relationship between them (Soebijantoro et al., 2012).

From historical background above, there are differences in internal concept of Setia Hati in development strategy until it's divided and there are three paths of $\mathrm{SH}$, namely Setia Hati Panti, Setia Hati Terate and Setia Hati Winongo Tunas Muda. Eyang Suro's orientation is on the purity of teachings that cannot be taught to just anyone, with this strategy the quality of Setia Hati's teachings is maintained but has the effect of reducing number of memberships. This is inversely proportional to the two students who wanted to teach more openly (Maksum, 2009).

The seeds of conflict began to appear after the September 30, 1965 incident where warriors, especially from Setia Hati splinter, $\mathrm{SH}$ Terate and SH Winongo Tunas Muda were involved in physical clashes during the political event, even though the two brotherhood were never affiliated with one political party. Fights between warriors sometimes ended in death in Madiun Area. To signify their territory, each silat institution uses identity of the monument. The existence of youth members is a challenge for both brotherhoods, it's a matter of pride for teenagers if they get status as warriors. The process of finding their identity and they often break their oath when provoked by their emotions. The escalation of conflict has increased since fall of the New Order, number of cases of violence that occurred in districts was higher than in cities because the area and number of $\mathrm{SH}$ members were wider and scattered in districts. The conflicts that often occur are destruction and persecution (Maksum, 2009).

\section{Public Interest Relations (PIR)}

PIR becoming academic research interest between Public Relations and Public Interest (Brunner, 2017a; Hiebert, 2015; Johnston, 2017)but whether they do so ethically. Accordingly, a definition of ethical persuasion is derived by examining unethical propaganda. The paper then considers what standard might be used to assess the ethics of persuasion. The notion of "the public interest" - ubiquitously linked to ethical practice in public relations - is considered but found to be too elusive to guide the practice individual practitioners. Other more assessable standards are identified, as is a guiding approach to ethics. The approach to ethics adopted in this paper is rule utilitarianism. The methodology of this paper is deductive and derivative analysis, argument and synthesis, drawn from a broad body of literature.Findings- Persuasion can be ethical, and a definition of ethical persuasion is proffered. The public interest is not a standard that individual practitioners can determine, decide, know, or apply to assess the ethics of their practice. Ethical persuasion can, however, be assessed using other standards, discussed in the paper. Consequently, a set of criteria and standards to practicing ethical persuasion is developed. Research limitations/implications- The paper does not extend into a discussion of practical persuasive techniques. Therefore, an extension of this examination could consider a thorough assessment of the ethics of practical persuasive communication techniques.Practical implications- Directly relevant to the daily work of public relations practitioners, communicators, adertisers and marketers, who are interested in acting ethically. The paper provide a basis for a guide to assessing the ethics of persuasive practice. Originality/value- This paper confronts both 
the question of whether practitioners can use the notion of the public interest to assess the ethics of practice, and also what constitutes ethical (and unethical. With relationship responsibility for the greater social good is a new challenge and opportunity for Public Relations (McKie \& Heath, 2016) challenges will arise when there is an interest from each individual or group to work together in public interest (Stoker \& Stoker, 2012). Work to integrate multiple goals but focus primarily on public interests rather than organizational interests (Andersen \& Johansen, 2016; Kim \& Slotegraaf, 2016). Organization responsibility isn't only demanded by interests of organization itself, but must be able to facilitate all aspects that occur in society (Tench \& Yeomans, 2017). PIR is different from Corporate Social Responsibility-CSR, traditional corporate social responsibility practices consider public interest but majority still prioritizes the organization (Park \& Dodd, 2016). According to Brunner \& Smallwood (2019), some PIR practices that an organization can carry out to integrate various interests are:

First, creating room for dialogue. Relations and dialogue are necessary for public relations to support democratic elements of society (Yang \& Taylor, 2013). When public relations helps public to trust each other through the flow of information, it serves the interests of public, community and society through dialogue (Heath, 200o; Fadillah \& Jandevi, 2020). PR can be used to create a room for dialogue on topics of interest to the public.

Second, encourage and listen to multiple perspectives. Public interest requires people to take part in larger discussions that affect society, listening to a variety of perspectives can encourage making a contribution (Moglen et al., 2017) because in a democracy everyone has the right to speak out and try to persuade each other so it can help innovative thinking in organizational decision making (Toledano, 2016). Through respectful dialogue we grow and become stronger (Pyle et al., 2018).

Third, offer honest analysis and recommendations regarding public interest. In order to prioritize public interest, practitioners need to ask questions such as: Are we creating opportunities to get involved in public matters?; Are our actions responsive to problems identified by society? and, does society believe it when we say we want to help? (Mitchell, 2017). Here, practitioner can advise the leader of organization on how best to serve public interest. Public interest practitioners must serve as reminders to others that to be effective. PR practitioners (corporate, government, nonprofit, and activist) not only have capacity to act, but also competence in having an influential voice (Richards, 2017).

The results obtained in implementing PIR practices are: gaining trust, building community, and fostering goodwill for all stakeholders. Trust is widely accepted as an essential part of public relations and this outcome can only be built with time (Hon \& Grunig, 1999)however, much of this work remains highly fragmented in nature. This article develops a tripartite organizational theory model that attempts to explain the relationship between advertiser and advertising agency. The model examines this relationship prior to, during and subsequent to the contracting process. In the empirical section of the article two facets of the model are tested:

\section{Conflict Management through stakeholder collaboration}

Definition of "peacebuilding" has evolved over time, those terms such as conflict management, conflict resolution or conflict transformation and many other (Broome \& Collier, 2012; Paffenholz, 2014). The conflict management process requires appropriate management strategies and methods that will produce positive results included in conflict negotiations (Ivana \& Krishnamurthy, 2019).

Collaboration means a group of people who have a common goal in solving a problem or in learning together (Cress et al., 2016). Collaborative action must be 
at the heart of a framework that begins with problem definition through to implementation which is impossible for a self-acting organization (Thomas \& Koontz, 2011), cooperation between stakeholders in Madiun is needed. According to Freeman, context of stakeholders is an individual, group or organization that can influence and be influenced "mutually influencing" in achieving a goal or solving a problem (Jiang \& Ritchie, 2017) and decision making can involve all stakeholders (Ansell \& Gash, 2008).

According to Maryono, stakeholders are divided into three groups (Yosevita, 2015): First, primary stakeholders: those who are fully involved in a series of plans because they are considered to have great influence and importance from a plan. Such a public figure, in this case is chairman of each silat institution in madiun. Second, key stakeholders: those who have right to make a policy because they have legal authority, such as govertment. Third, secondary stakeholders or supporters: those who have a high sense of concern for the process of a plan but aren't affected by anything and they can become facilitators. They are nongovernmental organizations, private sector.

\section{METHODS}

Descriptive qualitative used in this research. Qualitative research emphasizes drawing conclusions based on interpretation of facts and phenomena (Moleong, 2018) also based on social constructivism, which uses assumptions of individuals to understand the world (Creswell, 2009). As a key, researchers develop various kinds of meanings based on their life experiences (Sugiyono, 2011).

Data were obtained through semistructured interviews with Madiun Regency Government - Regent and related officials. To support research is also used literative study data of online articles, books and news. Case study is used to analyze the process of Public Interest Relations by stakeholders, especially Regional Government of Madiun Regency, which is a key stakeholder in handling social conflicts that occur in their area in creating a peaceful and safe atmosphere for its people. Efforts to prevent, stop and recover after conflict through reconciliation, rehabilitation and reconstruction are responsibility of the Regional Government (Soekanto, 2017).

Reviews conducted by previous researchers will be used as supporting data. This research focuses on efforts through the PIR approach in building stakeholder collaboration by looking at public interest. Validity of data uses data triangulation and theory as collection, data reduction, data presentation to conclusions.

\section{RESULTS AND DISCUSSION}

Every year just before Suran Agung tradition in Madiun region, stakeholders establish relationships by having dialogue and sitting together in deliberations to reach an agreement on common goals. What is a public issue in celebration of Suran Agung is peace and security for the public. In the deliberations, stakeholders also function as Public Relations. There is a reciprocal relationship, two-way communication is carried out in collaboration to fulfill common interests (Effendy, 2006) to get a good image, good intentions, tolerance and trust (Kasali, 2005). Efforts to build this relationship are made by judging what is a public issue to produce a policy for the best interest (Rumanti, 2002). Based on existing research and literacy, potential for conflict in commemoration of Suran Agung has become a public issue, because there was a very large mass mobilization in Madiun area.

From results of Maksum's (2009) research, there were 217 cases of violence from March 1998 to February 2007 in Madiun area. Some information can be accessed from online media from 2012 to 2015 that there were violent conflicts in Suran Agung, such as destruction of public facilities and fights between warriors and community which resulted in losses. (Eyato, 2014; Ishomuddin, 2012; Nugroho, 2013, 2015).

In research of Soebijantoro et al (2012) 
found that involvement of historical factors in Setia Hati brotherhood influenced warrior conflicts that occurred and had an impact on sociological situation of differences of opinion that occurred in generation of teachers and students regarding the concept of developing Setia Hati, although this difference was initially accepted by each organization. Conflict escalated quite sharply in 1990 s when number of members Setia Hati Terate and Setia Hati Winongo Tunas Muda grew. There is no organization sanction on members who break the oath into a habit that is repeated every year. Cultural approach with empowerment of pencak silat culture and dialogue is expected to become "glue of brotherhood" in conflict reconciliation efforts.

Meanwhile, in Sulistiyono's research (2013), there are various perceptions in society regarding the lack of information that has developed in society regarding the history and problems of conflict, causing rumors so that every month of Suro the stigma that arises is conflict due to large masses. Understanding of history and lessons is not always understood by some warriors, especially youth members. Conflict coverage that occurs continuously in media also influences the formation of opinion in society which makes it very familiar. This prejudice can be obtained through the process of learning and experience when seeing a conflict that occurs.

Listiana's research (2014) proves that dynamics of warrior conflict in Madiun are horizontal conflicts and open types of conflict because violence involves followers of silat institutions. Fanaticism among followers about purity of the teachings Setia Hati is one of the causes of potential conflict. Social support from Government for Pencak Silat organizations such as tournaments and existence of sanctions for rioters is expected to create a better social situation.

Research by Budiarto et al (2017) identifies things that can trigger potential conflicts, such as existence of a monument as the identity of territorial power of certain organizations that can break unity in society.
Conflict reconciliation efforts by Government include providing national insight, arranging schedule for the celebration of Suran Agung, holding seminars and martial arts festivals, making congratulations from one organization to another and forming the Madiun Pesilat Village community.

Meanwhile, Widiyowati et al. (2018) stated that the conflict management process requires an approach to local wisdom, cultural values are a way of life to achieve long-term peace. The mapping strategy also uses public figures who are considered key in realizing this peace because they are considered to have a strong role and influence in society.

With analysis of what are the public issues above, it is a momentum to make main focus to achieve peace, stakeholders in Madiun region come together for a common goal - this is what is called Public Interest Relations (PIR). Because these "key, primary and supporting" stakeholders also carry out the function of Public Relations, they can also be called agents of change - because PIR also always leads to collaboration (Jounghwa \& Yoonhyeung, 2009). And as agents of change in social conflict, when implementing PIR practices they try to balance their organizational and public interests. Even in certain situations they have made decisions and taken action in public interest rather than their own organization.

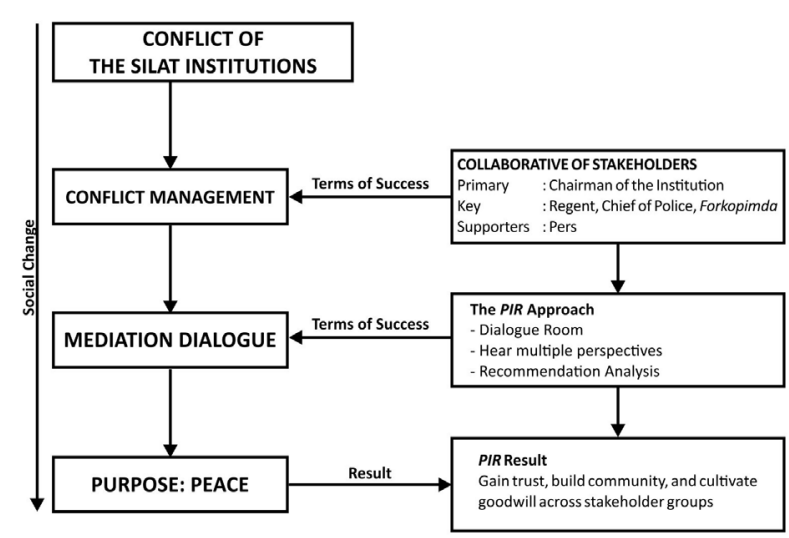

Figure 1. The Conflict Management Model uses Public Interest Relations (PIR) approach

The results of PIR practice implemented by stakeholders are : 
First, creating a dialogue room.

The first thing that stakeholders do continuously to build peace is to open room for dialogue. Commemoration in 2019 was mediated by key stakeholders: Madiun Regency Government, Madiun Resort Police and Madiun Military Regional Command also involved by primary stakeholders: fourteen leaders or figures from each of pencak silat institution in Madiun region and supported by secondary stakeholders: the press.

According to Martin Buber in Littlejohn (2017), in good dialogue we must respect all differences, we can express ourselves, but we must listen to and respect the ideas of others so that there is a mutual understanding. Humans are created as different individuals to communicate and dialogue in mutual understanding relationships.

Emphasize reconciliation by rebuilding broken relationships and strengthening peace-building that focuses on the root of problem (Paffenholz, 2014) Meanwhile, according to Benjamin Broome in Littlejohn (2017), in building dialogue to overcome sustainable violent conflict, it is highly recommended to use facilitator assistance as a mediation. Conflicts that occur in warriors (primary stakeholders) using government and law enforcement officials as facilitators (key stakeholders) and of course also supported by other parties such as the press (supporting stakeholders) in order to disseminate information to the public that can support a positive climate.

Creation of this dialogue room was facilitated by the Head of Police at Bhayangkara Building of Madiun Police on August 28, 2019 which was attended by Madiun Regent, Kodim Commander, Brimob Commander, Chairperson of IPSI Madiun, Chairperson of Setia Hati Terate, Chairperson of Setia Hati Tunas Muda Winongo and the press with agreement not to use motorbikes and pickups or trucks during the convoy. Also on August 30, 2019 at Tribrata field of the Madiun Police and followed by fourteen martial arts institutions - attended by at least 1200 warriors, in a relaxed atmosphere a pledge of peace was agreed and declared by the fourteen leaders of Pencak Silat institutions and other stakeholders.

The peace efforts facilitated by the police will not run maximally if attended only by certain circles -the elit (Listiana, 2013), but with the presence and collaboration of all stakeholders and attended by 1200 warriors, it becomes the right momentum in strengthening the potential for peace. At least fourteen different martial arts identities that meet each other can create a positive climate considering there is a sense of knowing each other in a common goal. Position of people as figures is key to effectiveness of conflict management because of the strong influence and role in society (Widiyowati et al., 2018).

This engagement strategy can be achieved through a variety of tactics including routine community meetings at a location to build relationships with stakeholders; attend such events organized by community groups; and involve communities who are elected, appointed and present leaders in their authority to establish discussions or dialogue relationships. The organization can be proactive in creating room for dialogue or it may discover tactics being implemented in reaction to expressed concerns (Brunner \& Smallwood, 2019). Transformation of the roles of stakeholders from year to year in preventing conflicts has been carried out continuously through dialogue and collaboration and realization of the pledges of peace made by the Regent, the police, the military command and all the Chair of Pencak Silat institutions (Harianto, 2019).

\section{Second, encourage and listen to multiple perspectives}

Arguments is not only about conflict, taking sides, choosing or defeating opponents - even winning, but engaging in discussion is a transformation of ideas that depend on negotiation, mediation, and conflict resolution (Moglen et al., 2017). With dialogue, it becomes open to criticism and new perspectives, thus encouraging organizations to engage in a strong exchange of ideas can offer each organization a 
competitive advantage. In addition, by encouraging several of perspectives, PIR can work effectively. In a relationship, each party will have a hope through their interactions and collaborations. Each time that hope is fullfilled, more trust will be built through communication and transparent disclosure. Building trust is a concern of PIRs through a focus on facilitating dialogue room (Brunner, 2019).

At least the primary stakeholders of each Pencak Silat institutions have the vision of their organization, but they agree on one goal for goodness in preserving culture of Pencak Silat and creating a peaceful atmosphere at celebration of Suran Agung. From the results of agreement made by all stakeholders, there is a pledge of peace in celebrating Suran Agung 2019 in Madiun: first, obeying the applicable legal rules and maintaining noble of values inherited by the silat institution. Second, mutual respect and build brotherhood between warriors. Third, realizing the peaceful Suro 2019 by supporting a safe and conducive situation.

As a key stakeholder, Regent of Madiun - Ahmad Dawami wants to change mindset terrible of Suro celebration into an attractive cultural tourism package so that it becomes a positive impact in Madiun area and realizes month of Suro as a zero accident. (detik.com,2019; humasmadiunkab, 2019) and Madiun Police Chief, Ruruh Wicaksono as person in charge of security in their area also wants to create a safe and conducive environment for community until peace of Suro declaration was realized as an agreement of three stakeholders.

\section{Third, offer honest analysis and recommendations regarding public interest.}

By offering honest analysis to an organization, public relations practitioners encourage organizational leadership not only to pursue short-term goals but as a long-term vission while working in public interest. Tactics for achieving this strategy include empowering public relations at the top decision-making level; doing market research and reputation; also continue monitoring the problem (Brunner \& Smallwood, 2019).

In dialogue, these stakeholders do not only voice their aspirations, but they have the capacity to carry out their vision and mission. They are people who have influence in society. Like the Regent of Madiun, Ahmad Dawami who wants to create a Safe Madiun - according to his political vision. The police through Madiun Police Chief, AKBP. Ruruh Wicaksono certainly wants to keep for safety in his area, while fourteen heads of Pencak Silat also support creation of peace by building brotherhood and developing silat culture. They are not only competent to act; they also have powerful voices and decision makers.

Support for establishing relationship between silat institutions is in harmony as stated by the heads of two largest brotherhoods in Madiun, Setia Hati Terate and Setia Hati Winongo Tunas Muda that they are brothers. In an interview by Soebijantoro et al (2012) to General Chairperson of SH Terate, H. Tarmadji Boedi Harsono, "we have no problems with other institutions" the phenomenon of violent conflict that occurs is a form of delinquency in adolescents which naturally will stop by itself. Same statement was also stated by Chairman of SH Winongo Tunas Muda that clash between two institution was due to involvement of other parties who were not responsible for personal gain, "we never teach term of mortal enemy to our new members, there is no such term, our enemy is devil "said RM Agus Wijono Santoso. Two heads of institutions also stated, if there are members who violate their oath it will be a personal risk, organization will only try to help to rectify. However, if violation is related to legal issues, of course, it will be processed to according applicable law.

AccordingtoIPSI, conflicts occurbecause a lack of legal awareness in the community, weak coaching from institutions, there are no strict sanctions for violators the pledge of peace and result in repeated violations 
by irresponsible people (Sulistiyono, 2014). Based on research by Maksum (2009) there are factors that trigger potential for violent conflict between warriors or community in Madiun:

First, social, political and economic conditions. This occurs when it involves emotionally in mobilizing the masses for support purposes - for example in elections that can potentially trigger a conflict. Potential conflicts easily happens to mass groups in social and economic inequality such as unemployment and poverty. (Anwar et al., 2005; Rozi, 2006). Number of poor people in Madiun Regency reaches 77,750 people or $11.42 \%$ of the total population. Percentage of poverty is still quite high compared to East Java Province which reached $10.98 \%$ (Haryono, 2019). Based on data from BPS Madiun 2018, population of Madiun Regency has reached 681,394 people and there are 14,357 people with unemployment status. According Cohen in Maksum (2009) to achieve a goal, someone can easily mobilize another who has free time.

Second, the loss of trust in government and legal system. Conflict between silat institutions has occurred in a long period since the end of New Order era, Escalation of conflict occurred together with the public's distrust of government and judicial institutions that seemed do nothing. An interview conducted by Ali Maksum found the fact that people involved in violent conflict weren't given deterrent punishments; only by paying amount of money they could be free from legal traps. Existence of unfair treatment from security forces, such as certain group convoys deliberately being allowed to use pickups; while other groups are being punished also affects this sense of trust. Actions from security forces and organizations are needed as a deterrent effect for those involved in criminal acts (Listiana, 2013).

Third, learning physical exerciseviolence. Madiun has long history of conflict, since Mataram kingdom which attacked
Purbaya-Madiun, until after proclamation which was a dark tragedy for Indonesian people in 1965. Physical exercise in Pencak Silat is a medium for mastery of martial arts through specific movements. Through repeated learning activities, a person can perceive that he has advantage of martial arts than others. Title of "warrior" has its own pride for someone who has passed the training program that he is taking. Potential for violence will appear in individuals when they have a belief in a value (Lopez \& Emmer, 2002).

According to Draeger, Indonesia once had great knights and masters of martial arts, also had a large number of soldiers during times of great empires like Sriwijaya and Majapahit. At that time, Indonesian people had used both combination of weapons and silat as an inseparable martial art. Not only in physical exercise, but both are closely related to spiritual relationship with Indonesian culture (Mardotillah \& Zein, 2017).

Fourth, prejudice to group solidarity. This happens because there is confidence in individuals, where the group is better at applying the teachings of Setia Hati. From Ali Maksum's interview, they tend to dislike other groups even if they don't have any personal problems, but if they see an identity of another group, there is an intention to antagonize it. If there's conflict with members and involves the identity of other groups, violence will potentially arise under pretext spirit of brotherhood in defending the group. Indoctrination to keeping brotherhood in the group has been taught to new members, it should aim for goodness, but it becomes a different meaning for certain members. According to Irving Janis in Littlejohn (2017), in groupthink theory, a high level of cohesion - mutual interest among members of the group, under certain conditions can lead to poor decision making. In the research of Soebijantoro et al. (2012) and Budiarto et al. (2017), existence of each social identity such as a symbol or monument as a territory of power can trigger a potential conflict. Existence of symbols can affect the unity in society and there is social 
polarization in both silat organizations.

Fifth, the age factor. Conflict easily occurs in adolescent members. When a coach was a teenager with bachelor status, they often get into physical clashes in fights, but as time grows older or is married and has children, they have better emotional maturity. According to Erikson, stage where the identity crisis occurs during adolescence, various kinds of behavioral deviations in adolescents is a process of affirming an identity which sometimes becomes negative (Santrock, 1996).

\section{Results of Public Interest Relations (PIR)}

With PIR approach in resolving a long tradition of conflict history by prioritizing the public interest where all stakeholders want to realize, Madiun Regency Government on October 222018 has launched a new identity, namely Indonesian Pesilat Village as the unifier of all silat institutions in Madiun area and can improve welfare for the community. As quoted from official website of the Madiun Regency Government, Ahmad Dawami b subaltern counterpublics, and the elieves: Madiun Regency will be safer with many pencak silat institutions, this is consintent with the main vision of Madiun Regency Government: Safe, Independent, Prosperous and Moral.

With diversity of silat institutions centered in Madiun, it will be an energy in development of Madiun Regency through the branding of Indonesian Pesilat Village. According to the Regent, launch of a new identity was first step to equalizing the perception of one goal in developing Madiun Regency, so that elements of hostility could be avoided. The Regent also said on the anniversary of Madiun Regency on July 17, 2019 at Ronggo Jumeno Hall:

"The main thing is to equate perceptions first, then we will move on to another tourism potential and achievement".

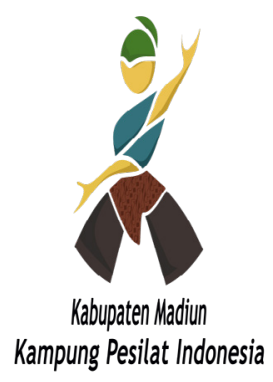

Figure 2: Indonesian Pesilat Village Logo, Source: PR of Madiun

With the large number and identity of silat institutions in Madiun, they are united into a new identity. Through a cultural approach as local wisdom in Madiun, it is a reconciliation of conflict towards peace. This is in line with the research of Soebijantoro et al. (2012) Budiarto et al. (2017) and Widiyowati et al., 2018, who propose a cultural approach as a conflict management effort for warriors in Madiun.

When people have a belief in cooperation and participation, this is building community and goodwill in dialogue (Brunner, 2017a; Sommerfeldt, 2013)some have critiqued the public sphere on grounds of equal access and portrayed civil society as a guise for first-world imperialism. These critiques have implications for the role of public relations in the public sphere and civil society. This article suggests the normative role of public relations in democracy is best perceived as creating the social capital that facilitates access to spheres of public discussion and in maintaining relationships among those organizations that check state power. To that end, the paper argues that social capital does much to advance public relations theory and prescribe the role of public relations in democracy. Several implications for public relations from a social capital perspective are offered, including the creation of generalized societal trust, the building of cross-cutting or "weak" ties, the engagement of media on behalf of subaltern counterpublics, and the (building a cycle of trust in society, the role of Public Relations is not only prioritizing short-term goals in the organization, but also long-term vision and mission when working for public interest (Brunner \& Smallwood, 
2019). Peace building is important for the welfare of public and many are explained in the concepts and techniques in Public Relations and as a scientific discipline, Public Relations must prioritize public issues in building concept of peace rather than other interests (Brunner \& Smallwood, 2019; Ivana \& Krishnamurthy, 2019).

The efforts of stakeholders in peace between warriors have been built over a years, reduction of violent conflict is a social dynamic that is happening better and commemoration of Suran Agung 2019 in Madiun is safe. Quoted from the statement of the Madiun Police Chief, AKBP Ruruh Wicaksono:

"The results of monitoring on Suran Agung activities were conducive and had zero accidents. Group of warriors from Wonogiri, Pacitan, Ponorogo, Trenggalek were escorted by the police. They go to Madiun by truck and bus" (Bagus, 2019).

Two regional heads in Madiun area, the Mayor - Maidi and the Regent - Ahmad Dawami stated that 2019 Suran Agung commemoration has been running safely and conducive, even in 2020 it will be scheduled on tourism potential. Because Madiun area has many Pencak Silat institutions, in 2017 Imam Nahrawi as the Minister of Youth and Sports wants to make Madiun area a destination for pencak silat (Nugroho, 2017). As the party that has authority to control the area, Madiun Regency Government collaborates with other stakeholders to implement PIR practices in an effort to build peace at commemoration of Suran Agung in Madiun Regency area.

\section{Collaboration of Stakeholders in Building Peace through Public Interest Relations (PIR)}

Collaboration can reduce conflict, create solutions, minimize failures on planning, create strategies for the needs of all parties involved and produce long-term solutions. Main principle of collaboration is transparency of the process, diversity and representation of stakeholders, including involvement of all stakeholders in making a policy. Collaboration of stakeholders as an effective way of realizing conflict reconciliation, involving community leaders and being supported by other parties in maintaining social security, such as babinsa - the police, and the government as person in charge is a form of collaboration. Involvement of collaborating parties is a form of active support for realization of peace between pencak silat institutions in Madiun Regency. Collaboration in Public Interest Relations (PIR) is a method of creating a situation where two or more parties contribute to each other as stages of achieving common goals. Public Relations must be able to place public interest at center of decision making, communication and action (Brunner \& Smallwood, 2019; DuBrowa, 2018), is a failure of Public Relations if it only prioritizes organizational interests without considering interests outside the organization (B. R. Brunner, 2019). Works in public interest the results will have a positive impact on the organization (Swart, 2011). Results of PIR, have been transformed by stakeholders into a new identity, namely Indonesian Pesilat Village, which is an effort for peace in social change. According to R. Racliffe Brown, the meaning of identity is a form in individuals in society and because of the habits and beliefs that are manifested, thus creating and preserving a certain function and structure (Mahendra, 2013). The existence of identity Indonesian Pesilat Village is a dynamic patterned from time to time through a cultural approach, this built in line with the vision and mission of Madiun Regency Government with other stakeholders in creating a sense of security, more independence and prosperity for its people.

\section{CONCLUSION}

Handling of violent conflicts that occurred in Madiun during celebration of Suran Agung from year to year is getting better. Stakeholders hope that in the following year, identity of Indonesian Pesilat Village can be preserved and developed to 
support the economy in Madiun region. In this PIR practical research there are deficiencies because identity of Indonesian Pesilat Village in Madiun is relatively new and there are several questions that need to be answered in further research to determine the value of PIR theory : does practicing PIR lead to results of the trust, community, also community goodwill? How can PIR be measured and evaluated? This seems quite difficult to measure and evaluate because the dynamics of public interest are changing very rapidly. We realize that there isn't precise measurement approach to the concept of public interest because of the rapid changes and this is of concern to practitioners.

\section{REFERENCES}

Andersen, S. E., \& Johansen, T. S. (2016). Cause-related marketing 2.0: Connection, collaboration and commitment. Journal of Marketing Communications, 22(5), 524-543. https://doi.org/10.108o/13527266.2014. 938684

Ansell, C., \& Gash, A. (2008). Collaborative governance in theory. Journal of Public Administration Research and Theory, 18. https://doi.org/10.1093/jopart/ mumo32

Anwar, D. F., Bouvier, H., Smith, G., \& Tol, R. (2005). konflik kekerasan internal: tinjauan sejarah, ekonomi-politik, dan kebijakan di Asia pasifik.

Bagus, R. (2019). Suran Agung di kota Madiun berlangsung lancar, meski diwarnai konvoi, Walikota Maidi titip wejangan. Surya.Co.Id. https://surabaya. tribunnews.com/2019/o9/16/suranagung-di-kotamadiun-berlangsunglancar-meski-diwarnai-konvoiwalikota-maidi-titip-wejangan

Broome, B. J., \& Collier, M. J. (2012). Culture, communication, and peacebuilding: A reflexive multi-dimensional contextual framework. Journal of International and Intercultural Communication,
5(4), 245-269. https://doi.org/10.108o/ 17513057.2012 .716858

Brunner, B. (2017a). Community, engagement, and democracy: Reenvisioning public relations and public interest communications through civic professionalism. The Journal of Public Interest Communications, 1(1), 45. https://doi.org/10.32473/jpic.v1.i1.p45

Brunner, B. (2017b). The moral compass of public relations. Routledge.

Brunner, B. R. (2019). Public relations theory: application and understanding (pp. 141157). John Wiley \& Sons.

Brunner, B. R., \& Smallwood, A. M. K. (2019). Prioritizing public interest in public relations: Public interest relations. Public Relations Inquiry, 8(3), 245-264. https://doi. org/10.1177/2046147X19870275

Budiarto, A., Sihole, E., \& Budiantoro, R. (2017). Peran pemerintah kota Madiun dalam penanganan konflik perguruan silat Persaudaraan Setia Hati Terate dan Perguruan Silat Persaudaraan Setia Hati winongo tunas muda. Damai Dan Resolusi Konflik, 3(1), 3-29.

Cress, U., Moskaliuk, J., \& Jeong, H. (2016). Mass collaboration and education. https://doi.org/10.1007/978-3-31913536-6

Creswell, J. (2009). Research design: Qualitative, quantitative, and mixedmethod approaches (3rd ed.). SAGE Publications, Incorporated.

DuBrowa, C. (2018). The New CCO : Chief conscience officer. PR Week. https:// www.prweek.com/article/1459851/ new-cco-chief-conscience-officer

Effendy, O.U. (2006). Hubungan masyarakat: Suatu studi komunikologis. PT Remaja Rosdakarya.

Eyato, D. (2014). Polisi dan pesilat bentrok 2 luka. Sindonews.Com. https://daerah. sindonews.com/berita/922250/151/ polisi-dan-pesilat-bentrok-2-luka 
Fadillah, D., \& Jandevi, U. (2020). Mediasocial behavior of Muhammadiyah members in China in the framework of Alexander Wendt's international communication constructivism. Journal of Social Studies (JSS), 16(1), 5164. doi: 10.21831/jss.v16i1.34604.

Harianto, S. (2019). 14 Perguruan silat di Madiun berikrar jaga perdamaian di bulan Suro. Detiknews. https:// news.detik.com/berita-jawa-timur/ d-4686752/14-perguruan-silat-dimadiun-berikrar-jaga-perdamaian-dibulan-suro

Harsono, T. B. (200o). Menggapai jiwa terate. Madiun: Lawu Pos, 33-42.

Haryono, M. (2019). Angka Kemiskinan di Kabupaten Madiun masih lebih Tinggi Dibanding Jatim. Rri.Co.Id. https://rri. co.id/madiun/daerah/754155/angkakemiskinan-di-kabupaten-madiunmasih-lebih-tinggi-dibanding-jatim

Heath, R. L. (200o). A rhetorical perspective on the values of public relations: Crossroads and pathways toward concurrence. Journal of Public Relations Research, 12(1), 69-91. https://doi. org/10.1207/S1532754XJPRR1201_5

Hiebert, R. (2015). Introduction. Public relations review, 41(5), 715-718. https:// doi.org/10.1016/j.pubrev.2015.06.009

Hon, L. C., \& Grunig, J. E. (1999). Guidelines for measuring relationships in public relations. Gainesville, FL: Institute for public relations.

Ishomuddin. (2012). Massa dua perguruan silat perang batu di Madiun. Tempo. Co. https://nasional.tempo.co/ $\mathrm{read} / 443975 /$ massa-dua-perguruansilat-perang-batu-di-madiun

Ivana, M., \& Krishnamurthy, S. (2019). Public relations for peacebuilding: case study from Colombia. Corporate Communications: An International Journal, 25(1), 48-66. https://doi. org/10.1108/CCIJ-07-2019-0085

Jiang, Y., \& Ritchie, B. W. (2017). Disaster collaboration in tourism: Motives, impediments and success factors. Journal of Hospitality and Tourism Management, 31, 70-82. https://doi. org/10.1016/j.jhtm.2016.09.004

Johnston, J. (2017). The public interest: A new way of thinking for public relations? Public Relations Inquiry, 6(1), 5-22. https://doi. org/10.1177/2046147X16644006

Jounghwa, C., \& Yoonhyeung, C. (2009). Behavioral dimensions of public relations leadership in organizations. Journal of Communication Management, 13(4), 292-309. https:// doi.org/10.1108/13632540911004588

Joyohusodo, S., Wignyomijoyo, S., Suronagoro, R., Nuriman, Sukoco, Joyosumarto, Santoso, \& Hadikusumo, S.(1963).Buku Peringatan Persaudaraan Setia-Hati 1903-1963. Not Published.

Kasali, R. (2005). Manajemen public relation. Pustaka Utama Grafiti.

Ki, E.-J., Kim, J.-N., \& Ledingham, J. (2015). Public relations as relationship management: A relational approach to the study and practice of public relations: Second edition. https://doi. org/10.4324/9781315719559

Kim, Y., \& Slotegraaf, R. J. (2016). Brandembedded interaction: a dynamic and personalized interaction for $\mathrm{CO}^{-}$ creation. Marketing Letters, 27(1), 183193. https://doi.org/10.1007/s11002-0159361-2

Listiana, A. (2013). Dinamika konflik perguruan silat setia hati (Studi konflik Simon Fisher pada kasus konflik kekerasan Setia Hati Terate dengan Setia Hati Tunas Muda Winongo di Kabupaten Madiun). UNIVERSITAS AIRLANGGA.

Littlejohn, S. W., Foss, K. A., \& Oetzel, J. G. (2017). Theories of human communication. 11th Editions (11th ed.). Waveland Press, Inc, United states of America. 
Lopez, V. A., \& Emmer, E. T. (2002). Influences of beliefs and values on male adolescents' decision to commit violent offenses. Psychology of Men $\mathcal{E}$ Masculinity, 3(1), 28-40. https://doi. org/10.1037//1524-9220.3.1.28

Lutfi, M., \& Fathani, A. H. (2013). Hitam putih pendidikan: menyingkap realitas, merajut solusi. Universitas Brawijaya Press.

Mahendra, A. (2013). Konstruksi identitas sosial perguruan pencak silat pencak organisasi ranting Kecamatan Sidoarjo, Kabupaten Sidoarjo. Journal Universitas Airlangga, 2(2), 1-10.

Maksum, A. (2009). Konflik kekerasan antar kelompok perguruan pencak silat: Proses pembentukan identitas sosial yang terdistorsi. Dalam "Anima", Indonesian Psychological Journal, $24(2)$.

Mardotillah, M., \& Zein, D. (2017). Silat: Identitas budaya, pendidikan, seni bela diri, pemeliharaan kesehatan. Jurnal Antropologi: Isu-Isu Sosial Budaya, 18(2), 121-133. https://doi.org/10.25077/ jantro.v18.n2.p121-133.2016

McKie, D., \& Heath, R. L. (2016). Public relations as a strategic intelligence for the 21st century: Contexts, controversies, and challenges. Public Relations Review, 42(2), 298305. https://doi.org/https://doi. org/10.1016/j.pubrev.2015.04.003

Mitchell, T. D. (2017). The Next "Evolution" of civic learning. Association of American Colleges \& Universities. https:// www.aacu.org/peerreview/2017/Fall/ Mitchell

Moglen, S., Keetley, D., \& Crassons, K. (2017). Literature and Social Justice. Association of American Colleges \& Universities. https://www.aacu.org/ peerreview/2017/Fall/Lehigh

Moleong, L. J. (2018). Metodologi penelitian kualitatif (38th ed.). PT Remaja Rosdakarya.
Nugroho, N. D. (2013). "Suran Agung" ricuh, warga lempari konvoi pesilat. Tempo.Co. https://nasional.tempo. co/read/530289/suran-agung-ricuhwarga-lempari-konvoi-pesilat/ full\&view=ok

Nugroho, N. D. (2015). seribu polisi siaga bentrok antar-pesilat di Suran Agung. Tempo.Co. https://nasional.tempo. co/read/712704/seribu-polisi-siagabentrok-antar-pesilat-di-suran-agung/ full\&view=ok

Nugroho, N. D. (2017). Banyak perguruan silat, Menpora ingin Madiun jadi tujuan wisata. Tempo.Co. https:// nasional.tempo.co/read/857420/ banyak-perguruan-silat-menporaingin-madiun-jadi-tujuan-wisata/ full\&view=ok

Oetzel, J. G., \& Ting-Toomey, S. (2006). The Sage handbook of conflict communication: Integrating theory, research, and practice. Sage Publications. https://doi. org/10.4135/9781412976176

Paffenholz, T. (2014). International peacebuilding goes local: analysing Lederach's conflict transformation theory and its ambivalent encounter with 20 years of practice. Peacebuilding, 2(1), 11-27. https://doi.org/10.108o/2164 7259.2013 .783257

Parekh, B. (2008). Rethinking multiculturalism: Keberagaman budaya dan teori politik. Penerbit Kansiius.

Park, Y. E., \& Dodd, M. (2016). The Historical Development of Corporate Social Responsibility as a Strategic Function of Public Relations (pp. 15-27). https:// doi.org/10.4324/9781315646503-1

Pyle, A. S., Linvill, D. L., \& Gennett, S. P. (2018). From silence to condemnation: Institutional responses to "travel ban" Executive Order 13769. Public Relations Review, 44(2), 214-223. https:// doi.org/https://doi.org/10.1016/j. pubrev.2017.11.002 
Richards, C. K. (2017). A civic-rich framework for liberal education. Association of American Colleges \& Universities. https://www.aacu.org/ peerreview/2017/Fall/Richards

Rozi, S. (2006). Kekerasan komunal: anatomi dan resolusi konflik di Indonesia. Pustaka Pelajar.

Rumanti, M. A. (2002). Dasar-dasar Public relations teori dan praktik. PT Gramedia Widiasarana Indonesia.

Santrock, J. W. (1996). Adolescene (6th ed.). Dubuque, IA: Brown \& Benchmark Publishers.

Soebijantoro, S., Nurcahyo, A., \& Hartono, Y. (2012). Rekonsiliasi konflik antarperguruan silat di Madiun (Studi Historis Sosiologis). Agastya: Jurnal Sejarah Dan Pembelajarannya, 2(1), 100-124.

Soekanto, S. (2017). Sosiologi Suatu Pengantar. RajaGrafindo Perkasa.

Soewarno, R. D. J. (1994). Pusaka pencak silat dalam tiga zaman: Persaudaraan Setia Hati Winongo Tunas Muda. Special Book for foster sons.

Sommerfeldt, E. J. (2013). The civility of social capital: Public relations in the public sphere, civil society, and democracy. Public Relations Review, 39(4), 280289. https://doi.org/https://doi. org/10.1016/j.pubrev.2012.12.004

Stoker, K., \& Stoker, M. (2012). The paradox of public interest: How serving individual superior interests fulfill public relations' obligation to the public interest. Journal of Mass Media Ethics, 27(1), 31-45. https://doi.org/10.1 o8o/o8900523.2012.636242

Sugiyono. (2011). Metodologi penelitian kuantitatif kualitatif dan RED. Alfabeta.

Sulistiyono, R. (2014). Persepsi masyarakat terhadap konflik antar oknum perguruan pencak silat (studi kasus mengenai konflik antar oknum persaudaraan setia hati terate dan persaudaraan setia hati tunas muda Winongo di kabupaten Madiun). Jurnal Ilmiah Pendidikan SosiologiAntropologi, 4(1), 2-13.

Swart, J. (2011). That's why it matters: How knowing creates value. Management Learning, 42(3), 319-332. https://doi. org/10.1177/1350507610391591

Tench, R., \& Yeomans, L. (2017). Exploring public relations: global strategic communication (pp. 82-87). Pearson Higher Ed.

Thomas, C. W., \& Koontz, T. M. (2011). Research designs for evaluating the impact of community-based management on natural resource conservation. Journal of Natural Resources Policy Research, 3(2), 97-111. https://doi.org/10.108o/19390459.2011. 557877

Toledano, M. (2016). Advocating for reconciliation: Public relations, activism, advocacy and dialogue. Public Relations Inquiry, 5(3), 277-294. https:// doi.org/10.1177/2046147X16666595

Widiyowati, E., Kriyantono, R., \& Prasetyo, B. D. (2018). Model manajemen konflik berbasis kearifan lokal: Konflik perguruan pencak silat di Madiun-Jawa Timur. Komunikator, 10(1), 34-47.

Yang, A., \& Taylor, M. (2013). The relationship between the professionalization of public relations, societal social capital and democracy: Evidence from a crossnational study. Public Relations Review, 39, 257-270. https://doi.org/10.1016/j. pubrev.2013.08.002

Yosevita, L. (2015). Implementasi peran stakeholder dalam pengembangan ekowisata di taman nasional manusela (TNM) di Kabupaten Maluku Tengah. Jurnal Agroforestri, 10(1), 21-30. 